\title{
Weight Management in Primary Care
}

\author{
Susanne Maurer
}

Adimed - Zentrum für Adipositas- und Stoffwechselmedizin Winterthur / Zermed - Zentrum für Ernährungsmedizin, Winterthur, Switzerland

\author{
Keywords \\ Obesity · Conservative therapy $\cdot$ Diet $\cdot$ Exercise
}

\section{Summary}

Background: Obesity is one of the greatest public health challenges worldwide. It is not only a medical but also a philosophical, ecological, economic, sociocultural, and psychological problem as well as a severe consequence of our modern value definition to 'receive more and more'. Therefore, physicians are not able to treat obesity broadly and should not be used as tools to achieve certain weight goals. Methods: This article presents an outline of conservative obesity therapy. Using the key words 'obesity', 'diet', and 'exercise', a search was conducted in the PubMed and ScienceDirect databases for the period from 1995 to 2015. Results/Conclusion: The goal of obesity therapy is primarily the reduction of abdominal fat distribution. Only after achieving this main objective, weight loss reduction can be included by changes in eating and activity habits as well as further lifestyle modifications supplemented by weight-reducing medical, invasive, and/or surgical therapy measures in order to reduce obesity-associated comorbidities and to improve quality of life. A reduction of fat intake while avoiding unsaturated fatty acids, an optimization especially of the quality of carbohydrate and protein intake, an increase in physical activity (about 30-60 min per day) with individual adaption, and a personal, ongoing therapeutic leadership is necessary to reach the main goal, i.e. losing $5-15 \%$ of the initial weight.

(C) 2016 S. Karger GmbH, Freiburg

\section{Introduction}

The World Health Organization (WHO) defines obesity and overweight as 'abnormal or excessive fat accumulation that presents a risk to health' [1]. As one of the greatest public health challenges worldwide, the prevalence of obesity has tripled in many European countries since the 1980s. Obesity and overweight increase the risk of developing numerous so-called non-communicable diseases (NCDs) such as cancer, diabetes, and cardiovascular diseases and of causing a variety of physical disabilities and psychological problems. NCDs are the leading cause of death globally, being responsible for 38 million (68\%) of the 56 million deaths in the world in 2012 [2].

The following article mainly focuses on indications for obesity treatment as well as possible lifestyle interventions, which are the principal elements of any obesity treatment program.

Nevertheless, the formula of weight loss is simple: 'less input + more output $=$ obesity reduction' [3].

\section{Thresholds for Management}

The primary goal of weight management in primary care is to reduce the morbidity and mortality of overweight or obese patients and to improve psychological well-being and social function. To achieve this reduction in morbidity or mortality, the risks inducing these have to be decreased. The treatment should be tailored to the patient's individual needs and risk profile. In general, obesity interventions are used for patients with an increased risk of morbidity or mortality.

In the past, treatment was initiated based on anthropometric measures. The body mass index (BMI) was demonstrated as one important risk factor; in 1997, the WHO defined overweight as a BMI $\geq 25 \mathrm{~kg} / \mathrm{m}^{2}$ and obesity as a BMI $\geq 30 \mathrm{~kg} / \mathrm{m}^{2}[4,5]$. For obese non-smoker females, life expectancy is reduced by 7.1 years whereas obese non-smoker males have an average life expectancy

\section{KARGER}

(๑) 2016 S. Karger GmbH, Freiburg

Fax +497614520714
Dr. med. Susanne Maurer

Adimed - Zentrum für Adipositas- und Stoffwechselmedizin Winterthur

Zermed - Zentrum für Ernährungsmedizin

Lagerhausstrasse 9, 8400 Winterthur, Switzerland

dr.smaurer-wiesner@hin.ch 
reduction of about 5.9 years compared to normal-range BMI [6] However, the BMI is insufficient in evaluating a patient's individual risk profile. To acquire additional information, waist circumference measurements are used due to their correlation with visceral fat mass. A waist circumference over $102 \mathrm{~cm}$ in men and 88 $\mathrm{cm}$ in women is associated with increased cardiovascular and metabolic risks [7]. In the past years, more publications revealed that anthropometric parameters are helpful; however, they only partly mirror a patient's risk. A stratification of risks according to the Edmonton Obesity Score System (EOSS) offers an additional possibility to draft the treatment indications more independently from the BMI. According to this score system, comorbidities can be grouped into four categories, i.e. metabolic, mechanical, mental, and monetary (meaning social and economic conditions) - the $4 \mathrm{M}$ system. Depending on which comorbidity is shown, the patient can be assigned to a certain stage, ranging from stage 0 (no apparent obesity-related risk factors) to stage 4 (severe, potentially end-stage disabilities due to obesity-related chronic diseases). Therefore, the mortality is not increased even with a BMI $>40 \mathrm{~kg} / \mathrm{m}^{2}$ if no associated diseases of the $4 \mathrm{M}$ system are shown. With this score system, weight loss treatment can be adapted according to the stage or the kind of comorbidity. For example, patients with stage 1 or only metabolic comorbidities only need to lose $5-10 \%$ of their initial body weight to reduce those morbidities while patients with stage 2 or only mechanical comorbidities need to lose $10-20 \%$ [8].

In general, many medical complications associated with obesity can be improved by intentional weight loss, and even very modest weight losses were shown to affect cardiovascular and metabolic risk markers. A reduction of $40-50 \%$ in sum of risk factors can be achieved by losing $2.25 \mathrm{~kg}$ over 16 years [9].

The informative value of the BMI as a risk factor is limited. It is obvious that associated mechanical diseases correlate with the patient's weight. The pattern of abdominal fat distribution can be more significant and more informative regarding metabolic comorbidities. The identification of obesity states according to the EOSS provides a good means of determining treatment indications.

\section{Lifestyle Modifications}

\section{Nutrition and Energy Intake}

The nowadays very common high-fat diet is an independent risk factor for overweight and obesity [10]. Especially energy-dense and carbohydrate-rich food, e.g. soft drinks, consumed in childhood or adolescence predisposes children and teenagers to weight gain [11]. However, this weight gain varies due to the individual environment and the genetic background of individuals.

An increased intake of dietary fat leads to elevated cardiovascular and metabolic risks. Nonetheless, the composition of fat or fatty acids is as important as the total intake. An increased intake of saturated fat leads to impaired insulin action $[12,13]$. In contrast, an elevated intake of unsaturated fat improves insulin sensitivity [14,
15], especially omega- 6 polyunsaturated fatty acids, which were shown to have positive effects on increasing said sensitivity in diabetic patients [16].

In addition to the effects on insulin sensitivity, fatty acids influence the lipoprotein metabolism. Therefore, the quality of fatty acid composition is as important as the energy content in treatment. Replacement of saturated fat with unsaturated fat led to reduced low-density and very-low-density lipoprotein concentrations in patients with insulin resistance [17]. Long-chain omega-3 fatty acids lower the triglyceride levels without affecting insulin sensitivity [18]. The blood pressure can be reduced by intake of monounsaturated acids [19,20].

In order to adapt the treatment to the patient's needs, it is beneficial to adjust the composition of fatty acids individually. The best ratio for saturated, monosaturated, and polysaturated fatty acid intake is 1:1:1 instead of the more common 7:2:1 ratio.

The composition of carbohydrates is important for weight reduction as well. Carbohydrates differ in the speed of their absorption. Simple sugars can be absorbed more quickly and more efficiently. Therefore, food with the same amount of carbohydrates can vary in its hormonal effects as well as glucose response $[21,22]$. This observation led to the establishment of the glycemic index [23]. Food with low glycemic indices and mainly containing slowly absorbable carbohydrates was shown to prolong postprandial satiety $[24,25]$. This index is, however, only applicable for foods within the same food group [26]. The total energy content is still important. The impact of complex versus simple carbohydrates was shown in a study with ad libitum, fat-reduced (by $10 \%$ of total energy) regimen in overweight individuals. Both diets led to a significant reduction in body weight and the maintenance of fat-free mass after 6 months [27].

Several studies showed that the replacement of some carbohydrates with proteins led to a positive effect on body composition changes during energy restriction; therefore, body fat loss can be improved by an increased intake of dietary proteins while lean body mass can be better maintained [28]. Additionally, maintenance of the resting metabolic rate can be enhanced by a high-protein diet [29]. In general, the loss of energy when proteins are absorbed, processed, or stored is the highest among all nutrients with approximately $25-30 \%$ of ingested energy [30]. There are several studies that showed proteins promoting satiety and reducing appetite $[28,31]$; these findings are controversial though [32]. All in all, a high-protein diet was shown to be superior in improving insulin sensitivity [33] while not adversely affecting blood pressure [34], cholesterol or triglyceride levels [28, 35], and bone turnover $[35,36]$. When proteins are ingested in combination with carbohydrates, insulin secretion increases. Therefore, a separation of carbohydrate and protein intake can be suggested. A higher protein intake after weight loss can contribute to a better stability of the new weight [37].

\section{Conclusion}

High-fat diets are independent risk factors for overweight and obesity. The composition of fatty acids is important when treating 
an overweight patient and improving weight loss. Replacing saturated with unsaturated fat leads to reduced lipoprotein concentrations, while increased intake of unsaturated fat improves insulin sensitivity. In general, an intake of saturated, monosaturated, and polysaturated fat should be adjusted to a ratio of 1:1:1 and that of total fat to not more than 40-60 g/day. The composition of carbohydrate intake is important as well. Simple and complex carbohydrates differ in their speed of absorption. Diets with increased intake of either simple carbohydrates or complex carbohydrates showed a reduction in body weight as well as maintenance of fatfree mass. Insulin-resistant patients can profit from an optimization of the times of carbohydrate intake. We recommend a sufficient amount of complex carbohydrates in the morning and noon as well as passing on carbohydrates in the evening. High-protein diets improve insulin sensitivity.

\section{Diets}

\section{Low-Caloric/Low-Fat Diet}

A low-caloric diet is applied in most patients because it contains all essential micro- and macronutrients and requires minimal monitoring. This conventional diet restricts the total fat energy to less than $30 \%$ of total energy intake. It should have high amounts of complex carbohydrates and fibers; therefore, the intake of wholegrain cereals, vegetables, and fruit should be increased [38]. The total energy content varies between 1,200 and 1,800 kcal/day. However, in order to adapt the diet to the individual needs of a patient, it is more efficient to estimate the total energy requirements, depending on the average activity of this patient, and to subtract a certain number of calories. The deficit, which is mainly accomplished through a reduction in dietary fat, should be approximately 600 $\mathrm{kcal} /$ day. When reducing the fat intake by about $10 \%$, a weight loss of $2.9 \mathrm{~kg}$ over 6 months can be reached [39]. A reduction in dietary fat without total energy restriction leads to weight gain prevention in normal patients and to weight loss in those with overweight [40].

\section{Very Low-Caloric Diets}

Very low-caloric diets (VLCD) contain less than $800 \mathrm{kcal} /$ day. They are used when a larger, more rapid short-term weight loss is desired [41] and to avoid total fasting. Usually, such diets are prepared as formula diets; therefore, it is very likely that they do not contain all required micronutrients and lead to an intake of too much simple sugars. The weight loss resulting from such a diet is two to three times greater than with conventional diets (low-caloric/low-fat diets) [42]. Patients with a BMI above $30 \mathrm{~kg} / \mathrm{m}^{2}$ or above $27 \mathrm{~kg} / \mathrm{m}^{2}$ plus associated conditions may benefit from such a diet [41]. Short-term results are for example an improvement in arterial hypertension and insulin sensitivity [43]. However, such diets are not suitable for patients with heart diseases [44] due to the increased stress level that is associated with such a diet, as well as for those patients with renal failure [45]. Additionally, infants, children, and pregnant or lactating women are not suited for such diets [41]

\section{Low-Carbohydrate Ketogenic Diets}

In this diet, carbohydrate intake is restricted to $50 \mathrm{~g} /$ day, though ingestion of animal products such as meat, eggs, fish, etc. is not limited. A carbohydrate intake of less than $40 \mathrm{~g} /$ day leads to ketonuria which can be easily detected with a urine dipstick. Dietary adherence can be tested via this measurement $[46,47]$. A low-carbohydrate ketogenic diet is more effective in older or insulin-resistant patients [48]. However, many patients are unable to sustain low carbohydrate intake over long periods [47]. The production of glucose via gluconeogenesis is increased when the carbohydrate intake is reduced. Gluconeogenesis requires the mobilization of ketogenic amino acids. If those are not replenished via intake, muscular proteins are mobilized, leading to the promotion of cardiomyopathies.

\section{Conclusion}

Different kinds of diets are available. The conventional, low-caloric/low-fat diet restricts the total fat energy to $30 \%$. With this therapy, a long-term and regular observation is required. It contains all required macro- and micronutrients and is well realizable because it matches the normal composition of food. A weight loss of $2.9 \mathrm{~kg}$ over 6 months was found (reduction of fat intake by 10\%). High amounts of complex carbohydrates are favorable. Reducing only the dietary fat intake without adapting the total energy intake leads to weight gain prevention (normal patients) and weight loss (overweight patients).

VLCD contain less than $800 \mathrm{kcal} /$ day. Larger, more rapid weight loss can be achieved. However, these diets may not include all essential micronutrients due to their preparation as formulas. The weight loss is two to three times greater. Most suitable for such diets are patients with a BMI over $30 \mathrm{~kg} / \mathrm{m}^{2}$ or over $27 \mathrm{~kg} / \mathrm{m}^{2}$ plus associated conditions. This diet has proven itself as a first step to weight reduction.

Low-carbohydrate ketogenic diets restrict the carbohydrate intake to $50 \mathrm{~g} /$ day. Ingestion of animal products is not limited. Older or insulin-resistant patients profit more from such diets.

Especially regarding long-term support, the following approach has proven to be very helpful: First of all, to start weight reduction, a VLCD can be applied to generate some success at the beginning of therapy; thus, the patient does not have to think too much about the diet. After that, nutrition modifications, especially fat reduction, can be applied. Modern media, such as smartphones, apps, online counseling, and recalls via telephone, can be used as surveillance tools and to prove adherence to the diet. Every 4-6 months, the focus of dietetic treatment should change, e.g. focusing on carbohydrate restriction or protein emphasis. It is especially necessary to establish a practical controlling system, at least once per year, as long as the patient is willing.

\section{Physical Exercise}

Physical exercise is in general an important component of daily energy expenditure which is easily modified and therefore very suited to be included into weight loss programs. The effects depend 
on the duration and intensity of one exercise unit. Depending on the kind of exercise, e.g. strength training, endurance training, or a combination of both, different responses can be elicited.

Physical exercise can improve blood pressure [49] as well as increase insulin sensitivity [50,51], cardiovascular fitness [52], and fat oxidation $[53,54]$ independently from body weight. With regular physical training, abdominal fat can be mobilized [55]. Additionally, a study has brought to light that only 30 min of activity on most days of the week reduces the all-cause mortality by about 20 $30 \%[56]$.

The effect of physical exercise cannot be solely explained by the increase of energy expenditure during exercise. Studies showed that regular exercise results in small elevations in the resting metabolic rate $[57,58]$. However, there are other observations showing a decrease in the resting metabolic rate with exercise training [59, $60]$. Nevertheless, exercise training promotes the growth of skeletal muscles [61].

In order to lose weight, low-intensity exercise is usually recommended. With higher intensities, fat oxidation is more likely to be replaced by carbohydrate oxidation [62]. However, the absolute quantity of fat oxidized is increased by a higher amount of work. Therefore, higher intensities are more efficacious if the patient is not physically limited. To prevent weight gain, a caloric expenditure equal to walking 6-7 miles/week, i.e. approximately $30 \mathrm{~min} /$ day, is sufficient [63]. More physical activity, about 60-90 $\mathrm{min} /$ day, is required to maintain weight loss $[64,65]$. A study on the effect of exercise, with or without dieting, showed that overweight men lost an extra $3 \mathrm{~kg}$ over 30 weeks while overweight women lost $1.4 \mathrm{~kg}$ over 12 weeks [66].

Weight loss induced only by dietary restriction is accompanied by a decline in the resting metabolic rate, which is partly due to the reduction of fat-free mass. Whether physical exercise can prevent this reduction is still unclear. However, physical exercise without restriction of caloric intake only results in small changes in body weight. Weight loss, especially fat loss, can be promoted by aerobic exercise and a hypocaloric diet.

\section{Conclusion}

Physical exercise is important for weight loss programs. Blood pressure, insulin sensitivity, and so forth can be improved by regular exercise. Only $30 \mathrm{~min} /$ day of activity can reduce the all-cause mortality as well as prevent weight gain. More physical activity, about $60-90 \mathrm{~min} /$ day, is recommended for maintaining weight loss. Higher training intensities are recommended to increase the absolute amount of fat oxidized. This is only applicable if the patient is not physically limited. Physical exercise without any changes in caloric intake leads to rather small changes in body weight.

\section{Disclosure Statement}

The author is a consultant, speaker, and advisor, or receives research support from: Bayer, Mylan, Ethicon-Endosurgery, Novo Nordisk, OVIVA, Sanofi. The author does not have stock ownership.

\section{References}

1 WHO: Health Topics - Obesity. www.who.int/topics/ obesity/en/ (last access on 19.07.16)

2 WHO: Global Status Report on Noncommunicable Diseases 2014. WHO Press, 2014.

3 Sacks FM, Bray GA, Carey VJ, Smith SR, Ryan DH, Anton SD, McManus K, Champagne CM, Bishop LM, Laranjo N, Leboff MS, Rood JC, de Jonge L, Greenway FL, Loria CM, Obarzanek E, Williamson DA: Comparison of weight-loss diets with different compositions of fat, protein, and carbohydrates. N Engl J Med 2009;360:859-873.

4 Hubert HB, Feinleib M, McNamara PM, Castelli WP: Obesity as an independent risk factor for cardiovascular disease: a 26-year follow-up of participants in the Framingham Heart Study. Circulation 1983;67:968977.

5 Manson JE, Willett WC, Stampfer MJ, Colditz GA, Hunter DJ, Hankinson,SE, Hennekens CH, Speizer FE: Body weight and mortality among women. N Engl J Med 1995;333:677-685.

6 Peeters A, Barendregt JJ, Willekens F, Mackenbach JP Al Mamun A, Bonneux L; NEDCOM, the Netherlands Epidemiology and Demography Compression of Morbidity Research Group: Obesity in adulthood and its consequences for life expectancy: a life-table analysis. Ann Intern Med 2003;138:24-32.

7 Lean ME, Han TS, Morrison CE: Waist circumference as a measure for indicating need for weight management. BMJ 1995;311:158-161.

8 Sharma AM, Kushner RF: A proposed clinical staging system for obesity. Int J Obes 2009;33:289-295.
Wilson PW, Kannel WB, Silbershatz H, D'Agostino RB: Clustering of metabolic factors and coronary heart disease. Arch Intern Med 1999;159:1104-1109.

10 Astrup A: Healthy lifestyles in Europe: prevention of obesity and type II diabetes by diet and physical activity. Public Health Nutr 2001;4:499-515.

11 Ludwig DS, Peterson KE, Gortmaker SL: Relation between consumption of sugar-sweetened drinks and childhood obesity: a prospective, observational analysis. Lancet 2001;357:505-508.

12 Maron DJ, Fair JM, Haskell WL: Saturated fat intake and insulin resistance in men with coronary artery disease. The Stanford Coronary Risk Intervention Project Investigators and Staff. Circulation 1991;84:20202027.

13 Parker DR, Weiss ST, Troisi R, Cassano PA, Vokonas PS, Landsberg L: Relationship of dietary saturated fatty acids and body habitus to serum insulin concentrations: the Normative Aging Study. Am J Clin Nutr 1993;58:129-136.

14 Pelikanova T, Kohout M, Valek J, Base J, Kazdova L: Insulin secretion and insulin action related to the serum phospholipid fatty acid pattern in healthy men. Metabolism 1989;38:188-192.

15 Borkman M, Storlien LH, Pan DA, Jenkins AB, Chisholm DJ, Campbell LV: The relation between insulin sensitivity and the fatty-acid composition of skeletal-muscle phospholipids. N Engl J Med 1993;328: 238-244.
16 Summers LK, Fielding BA, Bradshaw HA, Ilic V, Beysen C, Clark ML, Moore NR, Frayn KN: Substituting dietary saturated fat with polyunsaturated fat changes abdominal fat distribution and improves insulin sensitivity. Diabetologia 2002;45:369-377.

-17 Swinburn BA, Boyce VL, Bergman RN, Howard BV, Bogardus C: Deterioration in carbohydrate metabolism and lipoprotein changes induced by modern, high fat diet in Pima Indians and Caucasians. J Clin Endocrinol Metab 1991;73:156-165.

18 Harris WS: n-3 fatty acids and serum lipoproteins: animal studies. Am J Clin Nutr 1997;65(suppl):1611S$1616 \mathrm{~S}$.

19 Stamler J, Caggiula AW, Grandits GA: Relation of body mass and alcohol, nutrient, fiber, and caffeine intakes to blood pressure in the special intervention and usual care groups in the Multiple Risk Factor Intervention Trial. Am J Clin Nutr 1997;65(suppl):338S-365S.

20 Trevisan M, Krogh V, Freudenheim J, Blake A, Muti P, Panico S, Farinaro E, Mancini M, Menotti A, Ricci G: Consumption of olive oil, butter, and vegetable oils and coronary heart disease risk factors. The Research Group ATS-RF2 of the Italian National Research Council. JAMA 1990;263:688-692.

21 Jenkins DJ, Wolever TM, Jenkins AL, Thorne MJ, Lee R, Kalmusky J, Reichert R, Wong GS: The glycaemic index of foods tested in diabetic patients: a new basis for carbohydrate exchange favouring the use of legumes. Diabetologia 1983;24:257-264. 
22 Jenkins DJ, Wolever TM, Kalmusky J, et al: Low-glycemic index diet in hyperlipidemia: use of traditional starchy foods. Am J Clin Nutr 1987;46:66-71.

23 Foster-Powell K, Holt SH, Brand-Miller JC: International table of glycemic index and glycemic load values: 2002. Am J Clin Nutr 2002;76:5-56.

24 Leathwood P, Pollet P: Effects of slow release carbohydrates in the form of bean flakes on the evolution of hunger and satiety in man. Appetite 1988;10:1-11.

25 Holt S, Brand J, Soveny C, Hansky J: Relationship of satiety to postprandial glycaemic, insulin and cholecystokinin responses. Appetite 1992;18:129-141.

26 Jarvi AE, Karlstrom BE, Granfeldt YE, Bjorck IE, Asp NG, Vessby BO: Improved glycemic control and lipid profile and normalized fibrinolytic activity on a lowglycemic index diet in type 2 diabetic patients. Diabetes Care 1999;22:10-18.

27 Saris WH, Astrup A, Prentice AM, Zunft HJ, Formiguera X, Verboeket-van de Venne WP, Raben A, Poppitt SD, Seppelt B, Johnston S, Vasilaras TH, Keogh GF: Randomized controlled trial of changes in dietary carbohydrate/fat ratio and simple vs complex carbohydrates on body weight and blood lipids: the CARMEN study. The Carbohydrate Ratio Management in European National diets. Int J Obes Relat Metab Disord 2000;24:1310-1318.

28 Layman DK, Boileau RA, Erickson DJ, Painter JE, Shiue H, Sather C, Christou DD: A reduced ratio of dietary carbohydrate to protein improves body composition and blood lipid profiles during weight loss in adult women. J Nutr 2003;133:411-417.

29 Torbay N, Baba NH, Sawaya S: High protein vs high carbohydrate hypoenergetic diet in treatment of obese normoinsulinemic and hyperinsulinemic subjects. Nutr Res 2002;22:587-598.

30 Nair KS, Halliday D, Garrow JS: Thermic response to isoenergetic protein, carbohydrate or fat meals in lean and obese subjects. Clin Sci (Lond) 1983;65:307-312.

-31 Westerterp-Plantenga MS, Rolland V, Wilson SA, Westerterp KR: Satiety related to $24 \mathrm{~h}$ diet-induced thermogenesis during high protein/carbohydrate vs high fat diets measured in a respiration chamber. Eur J Clin Nutr 1999;53:495-502.

32 Raben A, Agerholm-Larsen L, Flint A, Holst JJ, Astrup A: Meals with similar energy densities but rich in protein, fat, carbohydrate, or alcohol have different effects on energy expenditure and substrate metabolism but not on appetite and energy intake. Am J Clin Nutr 2003;77:91-100.

-33 Baba NH, Sawaya S, Torbay N, Habbal Z, Azar S, Hashim SA: High protein vs high carbohydrate hypoenergetic diet for the treatment of obese hyperinsulinemic subjects. Int J Obes Relat Metab Disord 1999;23: 1202-1206

\34 Foster GD, Wyatt HR, Hill JO, McGuckin BG, Brill C, Mohammed BS, Szapary PO, Rader DJ, Edman JS Klein S: A randomized trial of a low-carbohydrate diet for obesity. N Engl J Med 2003;348:2082-2090.

35 Farnsworth E, Luscombe ND, Noakes M, Wittert G, Argyiou E, Clifton PM: Effect of a high-protein, energy-restricted diet on body composition, glycemic control, and lipid concentrations in overweight and obese hyperinsulinemic men and women. Am J Clin Nutr 2003;78:31-39.
36 Skov AR, Toubro S, Ronn B, Holm L, Astrup A: Randomized trial on protein vs carbohydrate in ad libitum fat reduced diet for the treatment of obesity. Int J Obes Relat Metab Disord 1999;23:528-536.

37 Larsen TM, Dalskov SM, van Baak M, Jebb SA, Papadaki A, Pfeiffer AFH, Alfredo Martinez J, Handjieva-Darlenska T, Kunešová $M$, Pihlsgård $M$, Stender S, Holst C, Saris WHM, Astrup A: Diets with high or low protein content and glycemic index for weight-loss maintenance. N Engl J Med 2010;363:2102-2113.

38 Shah M, McGovern P, French S, Baxter J: Comparison of a low-fat, ad libitum complex-carbohydrate diet with a low-energy diet in moderately obese women. Am J Clin Nutr 1994;59:980-984.

39 Bray GA, Popkin BM: Dietary fat intake does affect obesity! Am J Clin Nutr 1998;68:1157-1173.

40 Astrup A, Ryan L, Grunwald GK, Storgaard M, Saris W, Melanson E, Hill JO: The role of dietary fat in body fatness: evidence from a preliminary meta-analysis of ad libitum low-fat dietary intervention studies. Br J Nutr 2000;83(suppl 1):S25-S32.

41 No authors listed: Very low-calorie diets. National Task Force on the Prevention and Treatment of Obesity, National Institutes of Health. JAMA 1993;270: 967-974.

42 Wadden TA: Treatment of obesity by moderate and severe caloric restriction. Results of clinical research trials. Ann Intern Med 1993;119:688-693.

43 Eliahou HE, Laufer J, Blau A, Shulman L: Effect of lowcalorie diets on the sympathetic nervous system, body weight, and plasma insulin in overweight hypertension. Am J Clin Nutr 1992;56(suppl):175S-178S.

44 Fisler JS: Cardiac effects of starvation and semistarvation diets: safety and mechanisms of action. Am J Clin Nutr 1992;56(suppl):230S-234S.

45 Pi-Sunyer FX: Medical hazards of obesity. Ann Intern Med 1993;119:655-660.

46 Hu G, Lindstrom J, Valle TT, Eriksson JG, Jousi-lahti P, Silventoinen K, Qiao Q, Tuomilehto J: Physical activity, body mass index, and risk of type 2 diabetes in patients with normal or impaired glucose regulation. Arch Intern Med 2004;164:892-896.

47 Yancy WS Jr, Olsen MK, Guyton JR, Bakst RP, Westman EC: A low-carbohydrate, ketogenic diet versus a low-fat diet to treat obesity and hyperlipidemia: a randomized, controlled trial. Ann Intern Med 2004;140: 769-777.

48 Stern L, Iqbal N, Seshadri P, Chicano KL, Daily DA, McGrory J, Williams M, Gracely EJ, Samaha FF: The effects of low-carbohydrate versus conventional weight loss diets in severely obese adults: one-year follow-up of a randomized trial. Ann Intern Med 2004;140:778785 .

49 Halbert JA, Silagy CA, Finucane P, Withers RT, Hamdorf PA, Andrews GR: The effectiveness of exercise training in lowering blood pressure: a meta-analysis of randomized controlled trials of 4 weeks or longer. J Hum Hypertens 1997;11:641-649.

50 Rice B, Janssen I, Hudson R, Ross R: Effects of aerobic or resistance exercise and/or diet on glucose tolerance and plasma insulin levels in obese men. Diabetes Care 1999;22:684-691.
51 De Feo P, Di Loreto C, Lucidi P, Murdolo G, Parlanti N, De Cicco A, Piccioni F, Santeusanio F: Metabolic response to exercise. J Endocrinol Invest 2003;26:851854.

52 Kraemer WJ, Volek JS, Clark KL, Gordon SE, Incledon T, Puhl SM, Triplett-McBride NT, McBride JM, Putukian M, Sebastianelli WJ: Physiological adaptations to a weight-loss dietary regimen and exercise programs in women. J Appl Physiol 1997;83:270-279.

53 Van Aggel-Leijssen DP, Saris WH, Hul GB, Van Baak MA: Short-term effects of weight loss with or without low-intensity exercise training on fat metabolism in obese men. Am J Clin Nutr 2001;73:523-531.

54 Schrauwen P, Lichtenbelt WD, Saris WH, Westerterp KR: Fat balance in obese subjects: role of glycogen stores. Am J Physiol 1998;274:E1027-E1033.

55 Mayo MJ, Grantham JR, Balasekaran G: Exercise-induced weight loss preferentially reduces abdominal fat. Med Sci Sports Exerc 2003;35:207-213.

56 Rockhill B, Willett WC, Manson JE, Leitzmann MF, Stampfer MJ, Hunter DJ, Colditz GA: Physical activity and mortality: a prospective study among women. Am J Public Health 2001;91:578-583.

57 Sjodin AM, Forslund AH, Westerterp KR, Andersson $\mathrm{AB}$, Forslund JM, Hambraeus LM: The influence of physical activity on BMR. Med Sci Sports Exerc 1996; 28:85-91.

58 Melby C, Scholl C, Edwards G, Bullough R: Effect of acute resistance exercise on postexercise energy expenditure and resting metabolic rate. J Appl Physiol 1993; 75:1847-1853.

59 Horton TJ, Drougas HJ, Sharp TA, Martinez LR, Reed GW, Hill JO: Energy balance in endurance-trained female cyclists and untrained controls. J Appl Physiol 1994;76:1936-1945.

60 Westerterp KR, Meijer GA, Schoffelen P, Janssen EM: Body mass, body composition and sleeping metabolic rate before, during and after endurance training. Eur J Appl Physiol Occup Physiol 1994;69:203-208.

61 Ryan AS: Insulin resistance with aging: effects of diet and exercise. Sports Med 2000;30:327-346.

62 Venables MC, Achten J, Jeukendrup AE: Determinants of fat oxidation during exercise in healthy men and women: a cross-sectional study. J Appl Physiol 2005; 98:160-167.

63 Slentz CA, Duscha BD, Johnson JL, Ketchum K, Aiken LB, Samsa GP, Houmard JA, Bales CW, Kraus WE: Effects of the amount of exercise on body weight, body composition, and measures of central obesity: STRRIDE - a randomized controlled study. Arch Intern Med 2004;164:31-39.

64 Erlichman J, Kerbey AL, James WP: Physical activity and its impact on health outcomes. Paper 2: Prevention of unhealthy weight gain and obesity by physical activity: an analysis of the evidence. Obes Rev 2002;3. 273-287.

65 Fogelholm M, Kukkonen-Harjula K: Does physical activity prevent weight gain - a systematic review. Obes Rev 2000;1:95-111.

66 Garrow JS, Summerbell CD: Meta-analysis: effect of exercise, with or without dieting, on the body composition of overweight subjects. Eur J Clin Nutr 1995;49: $1-10$. 